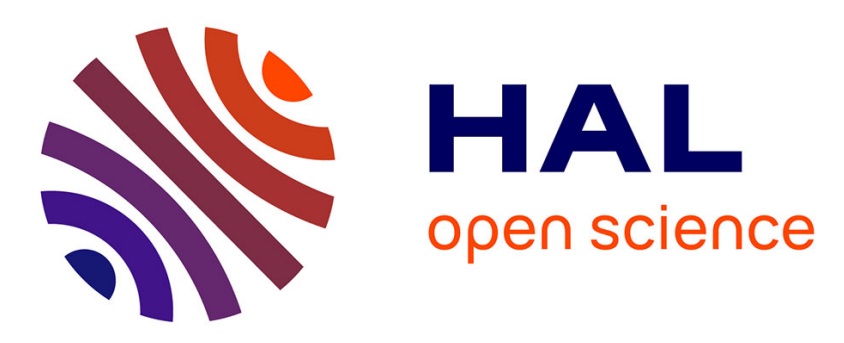

\title{
Identification of new hardy ferns that preferentially accumulate light rare earth elements: a conserved trait within fern species
}

Nicolas Grosjean, Damien Blaudez, Michel Chalot, Elisabeth Maria Gross, Marie Le Jean

\section{To cite this version:}

Nicolas Grosjean, Damien Blaudez, Michel Chalot, Elisabeth Maria Gross, Marie Le Jean. Identification of new hardy ferns that preferentially accumulate light rare earth elements: a conserved trait within fern species. Environmental Chemistry, 2020, 17 (2), pp.191. 10.1071/EN19182 . hal02523528

\section{HAL Id: hal-02523528 \\ https://hal.science/hal-02523528}

Submitted on 29 Mar 2020

HAL is a multi-disciplinary open access archive for the deposit and dissemination of scientific research documents, whether they are published or not. The documents may come from teaching and research institutions in France or abroad, or from public or private research centers.
L'archive ouverte pluridisciplinaire HAL, est destinée au dépôt et à la diffusion de documents scientifiques de niveau recherche, publiés ou non, émanant des établissements d'enseignement et de recherche français ou étrangers, des laboratoires publics ou privés. 


\title{
Identification of new hardy ferns that preferentially accumulate light rare earth elements: a conserved trait within fern species
}

\author{
Nicolas Grosjean, ${ }^{\mathrm{A}, \mathrm{B}}$ Damien Blaudez, ${ }^{\mathrm{B}}$ Michel Chalot, ${ }^{\mathrm{C}, \mathrm{D}}$ Elisabeth Maria Gross ${ }^{\mathrm{A}}$ \\ and Marie Le Jean ${ }^{\mathrm{A}, \mathrm{E}}$ \\ ${ }^{A}$ Université de Lorraine, CNRS, LIEC, F-57000 Metz, France. \\ ${ }^{B}$ Université de Lorraine, CNRS, LIEC, F-54000 Nancy, France. \\ ${ }^{\mathrm{C}}$ Université de Bourgogne Franche-Comté, CNRS, Laboratoire Chrono-environnement, F-25211, Montbéliard, \\ France. \\ ${ }^{D}$ Université de Lorraine, F-54000 Nancy, France. \\ ${ }^{\mathrm{E}}$ Corresponding author. Email: marie.lejean@univ-lorraine.fr
}

Environmental context. Rare earth elements (REEs) are strategic metals and emerging contaminants, for which accumulation in plants is poorly understood. Plant-based solutions are needed to remediate REE contaminated sites. Therefore, we screened a collection of hardy ferns and identified new REE accumulator species that preferentially transferred light REEs (LREEs) to their fronds. This study is an important step towards identifying LREE remediators and understanding REE accumulation in plants.

\begin{abstract}
Rare earth elements (REEs) include the lanthanides plus yttrium and scandium, and can be split according to their atomic mass into light (LREEs) and heavy REEs (HREEs). The increasing demand for REEs is mainly driven by new technologies, and their current low recyclability has led them to become emerging contaminants. The identification of new REE accumulators may help in determining the REE transfer mechanisms and may result in interesting candidates for phytoremediation techniques. To that end, a collection of 49 hardy fern species, grown in REE-spiked substrate, were screened for their potential in REE accumulation. REE concentrations were very low in the fronds of all Polypodium species, whereas all Athyrium species highly accumulated REEs. The REE accumulation level was more variable among the different species of Dryopteris, Blechnum, Woodwardia, Cystopteris and Polystichum. However, whatever the species, LREEs were preferentially transferred to the fronds over HREEs. This conserved trait was independent of the availability of different REEs in the substrate and instead may arise from specific transfer systems in ferns for the two groups of REEs. Furthermore, a correlation between REE accumulation and Ca and $\mathrm{Al}$ was found, which suggested the existence of common uptake pathways. Altogether, these results are of great interest for phytoremediation purposes since appropriate species can be chosen according to the
\end{abstract}


Environmental Chemistry

Volume: 17; Issue: 2; page: 191. Article ID: EN19182

DOI: $10.1071 / \mathrm{EN} 19182$

area to be remediated, and they also provide new insights into a more in-depth characterisation of the underlying REE accumulation mechanisms in ferns.

Additional keywords: Dryopteris, lanthanides, REE-accumulation, REE-fractionation, yttrium.

\section{Introduction}

Land pollution by metals has been widely reported and is considered as a major environmental problem. The rare earth elements (REEs) are a group of 17 metals sharing similar chemical and geochemical properties. This group contains the 15 lanthanides, as well as yttrium and scandium. The light REEs (LREEs, lanthanum to europium) and the heavy REEs (HREEs, gadolinium to lutetium) can be distinguished within the 15 lanthanides according to their atomic mass and ionic radius (Cotton 2006). The demand for REEs and the associated extraction of these elements has increased significantly; because of their unique properties, these elements are used in green energy, new technology and medical applications (Long et al. 2010; Ciacci et al. 2015). Overall, the production of lanthanides increased from $90000 \mathrm{t}$ in 2000 (Hedrick 2003 ) to $130000 \mathrm{t}$ of oxides in 2015 (Gambogi 2018). REEs are also commonly used as crop fertilisers to stimulate growth and production, and as a dietary supplement for cattle (Tyler 2004). Furthermore, high concentrations of REEs can be found in soils, especially around mining areas, where concentrations can reach more than $2000 \mathrm{mg} \mathrm{kg}^{-1}$, which is more than 10 times the global average soil concentration (Ramos et al. 2016). Associated with their mining and use, a crucial lack of recyclability for these elements currently exists (Binnemans et al. 2013; Ciacci et al. 2015). The recent substantial increase in the production and widespread use of REEs has begun to raise concerns about their impact on human and environmental health (Gonzalez et al. 2014; Zhuang et al. 2017). REE transfer throughout the ecosystem is now recognised as a potential problem because many studies have shown toxicological effects on bacteria, fungi, plants and animals (Rim et al. 2013; Pagano et al. 2015; Wakabayashi et al. 2016; Ikhlayel 2017). These observations are strong arguments for considering REEs as emerging pollutants.

Environmentally friendly phytoremediation solutions (i.e. phytoextraction) may help to reduce the high levels of REEs in soils through the use of REE-accumulating plants (Padmavathiamma and Li 2007; Liu et al. 2017). In general, the REE concentrations in plants range from $0.0011(\mathrm{Lu})$ to $0.33 \mathrm{mg} \mathrm{kg}^{-1}(\mathrm{Ce})$ (Djingova et al. 2001) and can reach up to $5 \mathrm{mg} \mathrm{kg}^{-1}$ (Ozaki et al. 1997). Although REEs are not considered essential for plants, it has been widely shown that they can be taken up and transferred to their aboveground biomass in moderate concentrations. Similar to other metals, a few plant species have been reported to accumulate REEs. The REE concentrations in Phytolacca americana (pokeweed) and Carya tomentosa (mockernut) can reach 1040 and $859 \mathrm{mg} \mathrm{kg}^{-1}$ respectively (Wood and Grauke 2011; Yuan et al. 2018). In addition to these two angiosperms, the majority of REE-accumulating plants belong to pteridophytes (Liu et al. 2017). The two species of fern that have the greatest capacity for REE accumulation are particularly 
interesting. Pronephrium simplex can accumulate up to $1200 \mathrm{mg} \mathrm{kg}^{-1}$ (Lai et al. 2005, 2006), while Dicranopteris dichotoma can contain up to $3300 \mathrm{mg} \mathrm{kg}^{-1}$ (Ozaki et al. 1997; Wei et al. 2001; Shan et al. 2003). It has been suggested that high concentrations of REEs in ferns may help these species adapt better to changing environments (Liu et al. 2017). Other fern species have also been mentioned as REE accumulators. Such species include Dryopteris erythrosora (Ozaki et al. 1997), Blechnum orientale (Zhang et al. 2002; Liang et al. 2014) and Athyrium yokoscense (Ichihashi et al. 1992), and the REE accumulation trait present in these species was identified from plants growing in non-contaminated environments. However, the number of REE-accumulating plants is limited to a relatively small number of species, and the potential of REE accumulation by ferns in a contaminated or enriched environment has rarely been studied so far.

The identification of new fern species that are able to accumulate REEs is of great interest, as it will allow for the selection of appropriate species adapted to a prospected area (soil, climatic conditions), for the determination of their use in environmental restoration and for the purpose of phytoextraction. Plant screening for new metal-accumulating species has already been done for several metals, including $\mathrm{Cr}$ (Shahandeh and Hossner 2000), As (Zhang et al. 2014), Pb (Salazar and Pignata 2014) and Cd (Wu et al. 2018). To identify new species that accumulate REEs and also to determine if this trait is conserved among certain genera, we have carried out a screening of fern species to determine their potential for REE accumulation. Unlike previous studies carried out under non-contaminated conditions (Ichihashi et al. 1992; Ozaki et al. 1997), in the present study, an extensive set of 49 fern species belonging to 15 different genera were screened by using soil enriched with REEs. This approach allowed us to identify new species of ferns accumulating REEs. In addition, unlike plants harvested in mining areas contaminated with LREEs, our experiment provided equimolar concentrations of specific LREEs ( $\mathrm{La}, \mathrm{Ce}$ and $\mathrm{Sm}$ ) and HREEs (Gd, $\mathrm{Yb}$ and $\mathrm{Y})$ so that the fractionation patterns in the fronds could be compared. The present study contributes to determining the global pattern of REE accumulation in planta and demonstrates that LREE preference is widely shared among ferns, which results from plant uptake or transfer mechanisms instead of REE availability in the substrate. The dichotomy between LREE preference in ferns and HREE preference in distant angiosperms, such as pokeweed or wheat, reveals the probable distinct underlying molecular mechanisms.

\section{Experimental}

Plant species, substrate preparation and growth conditions

Forty-nine fern species belonging to 15 different genera were used in the present study. The plants were purchased from a nursery specialising in hardy ferns, and the ferns were all grown with the same substrate at the nursery. The plants were first removed from their substrate and subsequently grown in an REE-spiked 


\section{Environmental Chemistry}

Volume: 17; Issue: 2; page: 191. Article ID: EN19182

DOI: $10.1071 /$ EN19182

substrate (peat $85 \%$ and perlite $15 \%$ mixture, with a fine granulation, particle size $1-7 \mathrm{~mm}: \sim 80 \%$, particle size 7-10 mm: 20\%; data obtained from the supplier Gramoflor GmbH \& Co, Germany).

The substrate was spiked with a total of $2000 \mathrm{mg} \mathrm{kg}^{-1}$ REEs (333 $\mathrm{mg} \mathrm{kg}^{-1}$ of La, Ce, Sm, Gd, Yb and Y). Hexahydrate salts of $\mathrm{LaCl}_{3}, \mathrm{CeCl}_{3}, \mathrm{SmCl}_{3}, \mathrm{GdCl}_{3}, \mathrm{YbCl}_{3}$ and $\mathrm{YCl}_{3}$ (Sigma Aldrich, Saint-Quentin-Fallavier, France) were used. An REE solution was sprayed onto a thin layer of substrate $(1 \mathrm{~cm})$ before a thorough hand mixing to ensure proper homogenisation of the contamination. The REE-spiked substrate was then placed into 3.4-L plastic pots $(20 \times 15 \times 15 \mathrm{~cm})$. This REE-spiked substrate was used for both the first and confirmation screens.

Plants were grown under controlled conditions in a phytotronic chamber $\left(18 / 23{ }^{\circ} \mathrm{C}, 12 / 12 \mathrm{~h}\right.$ dark/light cycles $\left.\left(260 \mu \mathrm{mol} \mathrm{m} \mathrm{m}^{-2} \mathrm{~s}^{-1}\right)\right)$ and watered twice a week. The aboveground biomass was harvested after 6 months of exposure. Fronds were thoroughly rinsed with deionised water to remove potential soil contamination. The samples were dried at $70{ }^{\circ} \mathrm{C}$ for two days and used for subsequent elemental analyses.

\section{Metal bioavailability determination}

The $\mathrm{CaCl}_{2}$-extractible fraction of REEs in the substrate was obtained according to the following procedure. After plant growth, for each replicate (i.e. three pots per species), the substrate was removed from the pot and aliquots were randomly collected at five different locations of the substrate. Three grams of the 2-mm-sieved substrate were dried at $60{ }^{\circ} \mathrm{C}$ for $48 \mathrm{~h}$ and incubated with $50 \mathrm{~mL}$ of $10 \mathrm{mmol} \mathrm{L}^{-1}$ calcium chloride under agitation (40 rpm) for $2 \mathrm{~h}$ at room temperature. The mixture was first filtered with ash-free filters, subsequently filtered at $0.45 \mu \mathrm{m}$ and acidified with $\mathrm{HNO}_{3}$ before inductively coupled plasma mass spectrometry (ICP-MS) analysis.

\section{Elemental analysis}

The quantification of elements was performed from $250 \mathrm{mg}$ of dried plant powder or from the acidified $\mathrm{CaCl}_{2}$-extractible fraction obtained as described above. For plant samples, mineralisation was carried out using $3.5 \mathrm{~mL}$ of nitric acid and $1 \mathrm{~mL}$ of hydrogen peroxide, and samples were incubated in a heating block digestion system (DigiPREP, SCP Sciences, Courtaboeuf, France). A gradual heating mode was used to achieve a final temperature of $100{ }^{\circ} \mathrm{C}$ (total run time of $265 \mathrm{~min}$ ). Then, ultrapure water (Millipore Milli-Q Integral 3 system, Molsheim, France) was added to a final volume of $25 \mathrm{~mL}$, and the samples were filtered through a $1-\mu \mathrm{m}$ mesh. REE concentrations were determined by using an ICP-MS instrument (X Series II Model, Thermo Fischer Scientific, Courtaboeuf, France) and other elements were analysed by an inductively coupled plasma atomic emission spectroscopy (ICP-AES) instrument (Radial ICAP 6500 Model, Thermo Fischer Scientific, Courtaboeuf, France). For plant samples, oriental basma tobacco leaves (INCT-OBTL5, LGC Promochem, Molsheim, France) were used as a certified reference material. For $\mathrm{CaCl}_{2}$-extracted 
substrate solutions, a surface water-trace metal standard (SPS-SW1, LGC Prochem standards, United Kingdom) was used as a certified reference material. Although only six REEs were added to the substrate, all 17 REEs were analysed by ICP-MS in the bioavailable fraction. Since their concentrations were very low (more than 15 (for Dy) to 8000 (for Tm) times lower than the concentrations of the 6 REEs added), they were not considered in this study (data not shown). In the following sections, for simplicity, the term 'REEs' will stand for the sum of the six REEs that were used.

\section{Statistical analyses}

One-way ANOVA and Tukey HSD post hoc tests were used when normality of data (Shapiro-Wilk test) and homoscedasticity (Levene's test) conditions were met. When at least one condition was rejected, the data were subsequently analysed using a one-way nonparametric Kruskal-Wallis test followed by Dunn's test. The rejection level was set at $5 \%$ in all analyses. Correlation analyses were performed using the $\mathrm{R}$ package Corrplot. All analyses were performed using $R$ software (version 3.4.1). All reported values are means \pm standard deviation (s.d.).

\section{Results}

\section{Identification of new REE-accumulating ferns}

Ferns were grown for six months and the REE concentrations in fronds were analysed by ICP-MS. Of the 49 species tested, three main REE accumulation patterns were observed. REE concentrations were very low ( $<10 \mathrm{mg} \mathrm{kg}^{-1}$ dry weight (DW)) in 10 species, 24 accumulated moderate levels between 10 and $100 \mathrm{mg}$ $\mathrm{kg}^{-1}$ REEs, and 15 species accumulated more than $100 \mathrm{mg} \mathrm{kg}^{-1}$ REEs in their fronds (Fig. 1). Of the ferns accumulating over $100 \mathrm{mg} \mathrm{kg}^{-1}$, only three reached more than $200 \mathrm{mg} \mathrm{kg}^{-1}$ (Fig. 1). This was the case for Athyrium filix-femina var. Victoriae, A. othophorum and Onoclea sensibilis. At the genus level, three REE accumulation patterns were observed. REE concentrations were very low $\left(<10 \mathrm{mg} \mathrm{kg}^{-1}\right)$ in all Polypodium species, whereas all Athyrium species accumulated high amounts of REEs (ranging from 130 to $220 \mathrm{mg} \mathrm{kg}^{-}$ ${ }^{1}$ ) (Fig. 1). The REE accumulation level was more variable among the different species of the other genera. In Dryopteris, large disparities were measured between species (Fig. 1). Two species accumulated less than $10 \mathrm{mg} \mathrm{kg}^{-1}$ (D. carthusiana and D. filix-mas), while the other species accumulated between 23 (D. cycadina) and 100 (D. marginalis) $\mathrm{mg} \mathrm{kg}^{-1}$ REEs. The known REE-accumulating species D. erythrosora accumulated up to $175 \mathrm{mg} \mathrm{kg}^{-1}$. Similar to Dryopteris, but to a lesser extent, Blechnum, Woodwardia, Cystopteris and Polystichum showed varying levels of REE accumulation. 
Environmental Chemistry

Volume: 17; Issue: 2; page: 191. Article ID: EN19182

DOI: $10.1071 / \mathrm{EN} 19182$

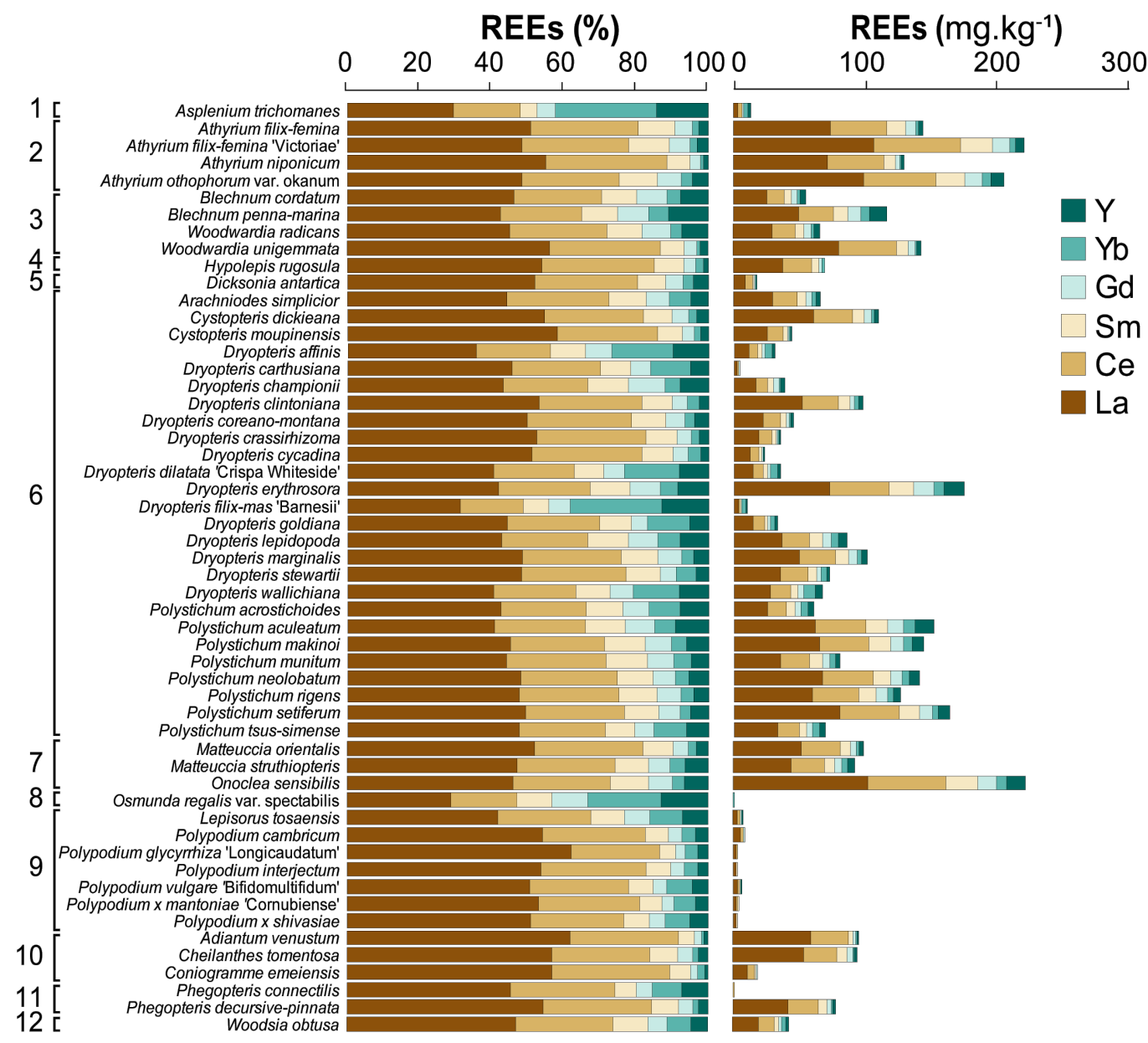

Fig. 1. Screening for accumulation potential of six REEs among fern species. On the left, the accumulation pattern of the six REEs in the fronds of 49 species is expressed as a percentage of the various REEs ( $\mathrm{La}, \mathrm{Ce}, \mathrm{Sm}, \mathrm{Gd}, \mathrm{Yb}$ and $\mathrm{Y}$ ) on the total of the six REEs accumulated. Species are organised by family: (1) Athyriaceae, (2) Blechnaceae, (3) Dryopteridaceae, (4) Onocleaceae, (5) Polypodiaceae, (6) Pteridaceae and (7) Thelypteridaceae. On the right, the accumulation of the six REEs in fern species is expressed as $\mathrm{mg} \mathrm{kg}^{-1} \mathrm{DW}$ of the above ground biomass. For the first screening, a single plant was tested for each species.

In the primary screening, we tested 49 species of hardy ferns. The species tested belonged to seven families, namely, Athyriaceae, Blechnaceae, Dryopteridaceae, Thelypteridaceae, within which some species have been previously shown to accumulate REEs (Liu et al. 2017), as well as Onocleaceae, Polypodiaceae and Pteridaceae (Fig. 1). However, none of the 49 species have been previously tested for their REE accumulation capacity, with the exception of Dryopteris erythrosora, which has been reported as an REEaccumulating species (Ozaki et al. 2000). The second screening included 14 species, which represented 28 $\%$ of the ferns tested in the first screening. This second screening was carried out in triplicate to confirm the results obtained from the first screening. We focussed our attention on 4 genera (Athyrium, Dryopteris, Polypodium and Polystichum) to represent different accumulating patterns (Fig. 2a). This second dataset confirmed the first screening, with Athyrium filix-femina and A. niponicum being species which strongly 
accumulated REEs, whereas the Polypodium species proved to be poor REE accumulators. Finally, a significant variation in REE concentrations was again observed among Dryopteris species (Fig. 2a).
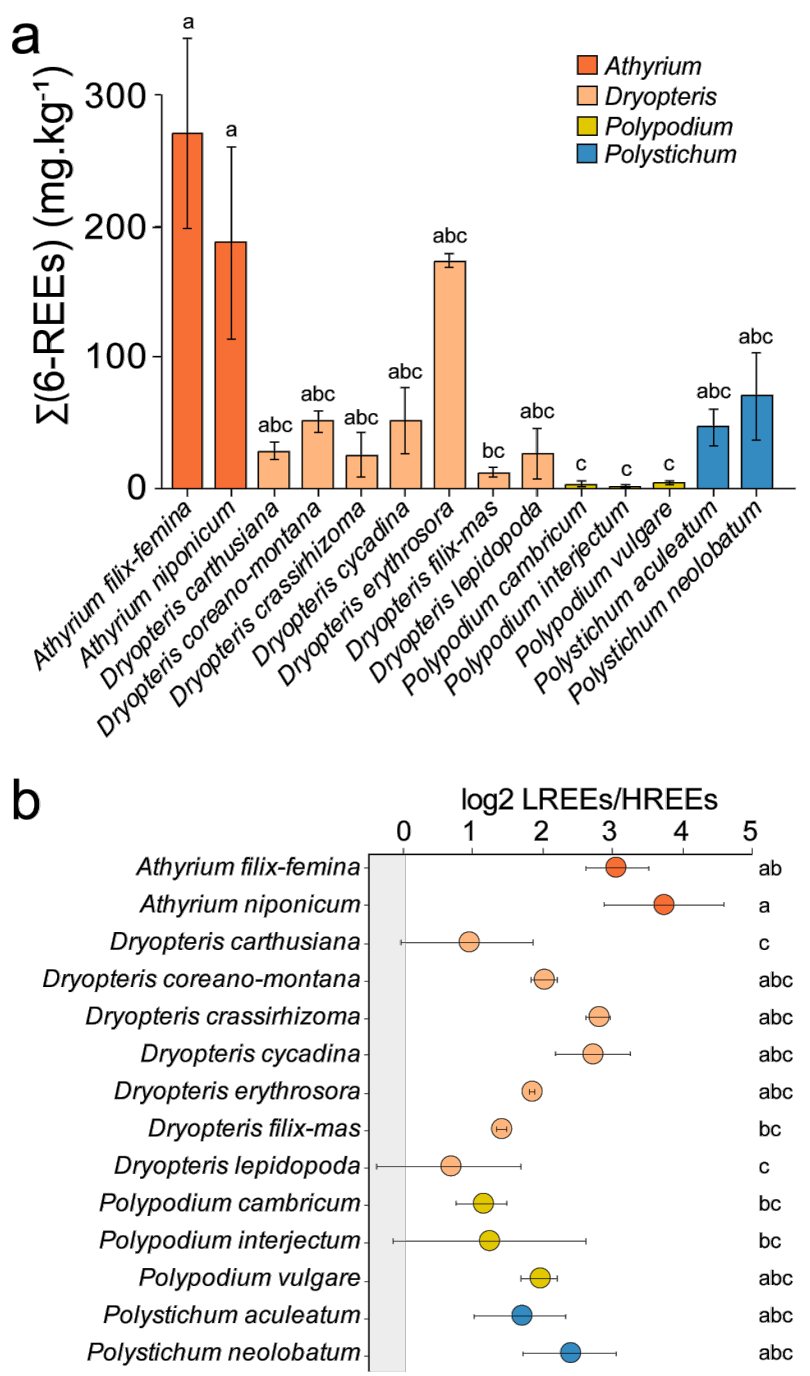

Fig. 2. Concentrations and fractionation of REEs in aboveground parts of ferns in the second screening. (a) Total concentrations of the six REEs in fern species harvested at the second screening ( $n=3$, mean \pm s.d.). (b) REE fractionation in fronds. $\log 2$ ratio of LREEs (La, Ce, Sm) to HREEs (Gd, Yb, Y) are given ( $n=3$, mean \pm s.d.). Bars topped by the same letter do not differ significantly between species $(P<0.05$, ANOVA followed by the Tukey HSD, or Kruskal-Wallis followed by the Dunn test).

\section{Preferential accumulation of LREES}

To investigate whether preferential accumulation of different REEs in the fronds of these ferns occurred, we analysed the fractionation pattern of REEs in different species. Interestingly, a similar behaviour was observed among all fern species studied in the first and second screenings (Fig. 1, Fig. 3). LREEs accumulated more than HREEs and accounted for between $70 \%$ and $90 \%$ of the total REE content (Fig. 1, 
Environmental Chemistry

Volume: 17; Issue: 2; page: 191. Article ID: EN19182

DOI: $10.1071 / \mathrm{EN} 19182$

Fig. 3), with the exception of Dryopteris filix-mas and D. affinis, which accumulated a little less LREEs (Fig. 1). This general LREE enrichment in ferns was confirmed during the second screening from the LREE/HREE ratios (Fig. 2b). The two Athyrium species accumulated 8 times more LREEs than HREEs, while in the Polystichum and Polypodium species, these ratios were 4 and 2 respectively (Fig. 2b). In Dryopteris species, the LREE/HREE ratios ranged from 2 (D. lepidopoda) to 8 (D. crassirhizoma). The highest REE-accumulating species of Dryopteris (D. erythrosora) had a ratio of 4 (Fig. 2b). In general, higher concentrations of La were found in all species, followed by Ce, Sm, Gd, Y and Yb (Fig. 3). However, in Polypodium species, $\mathrm{Yb}$ was more abundant than $\mathrm{Gd}$ and $\mathrm{Sm}$, which was similar to some Dryopteris species (Fig. 1, Fig. 3c-d).

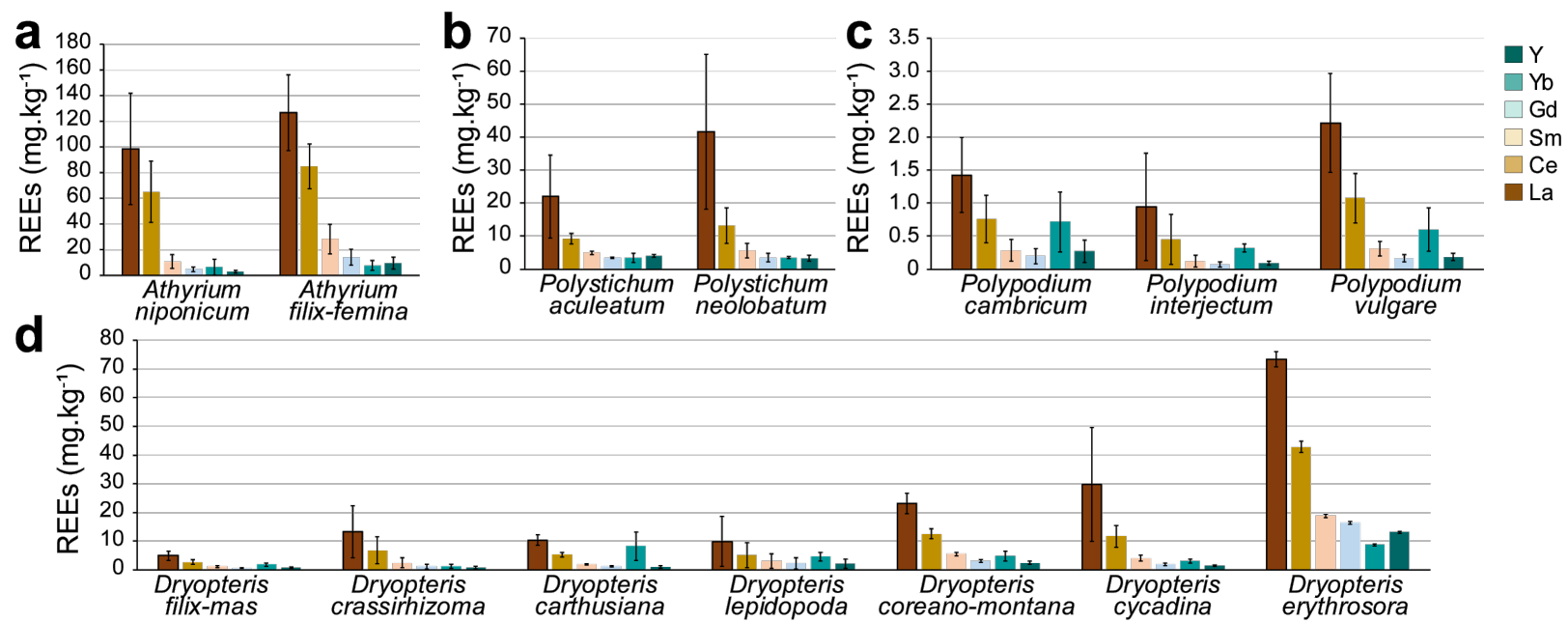

Fig. 3. Detailed concentrations of the six REEs in selected ferns in the second screening. REE concentrations in (a) Athyrium, (b) Polystichum, (c) Polypodium and (d) Dryopteris species. Plants were harvested after 6 months of growth in REE-contaminated substrate $(n=3$, mean \pm s.d.).

Since this preferential accumulation of LREEs could ensue from a higher bioavailability of LREEs compared with that of HREEs, we analysed the $\mathrm{pH}$ and the REE concentrations in the $\mathrm{CaCl}_{2}$-extractible fraction of the substrate from the pots of an REE-accumulating species (D. erythrosora) and a nonaccumulating species (D. filix-mas) (Fig. 4a). First, the substrate of the two species had very close pH values of $5.71+/-0.11$ for D. filix mas and $5.78+/-0.06$ for D. erythrosora (not significantly different). Second, the total REE extractible fraction was very low $\left(<1 \mathrm{mg} \mathrm{kg}^{-1}\right)$ in comparison to the total amount provided (2000 mg kg $\mathrm{g}^{-1}$ ). Only 0.05 to $0.25 \mathrm{mg} \mathrm{kg}^{-1}$ of each REE was retrieved in this fraction. Overall, the sum of the six REEs added was $0.53 \mathrm{mg} \mathrm{kg}^{-1}$ and $0.63 \mathrm{mg} \mathrm{kg}^{-1}$ for $D$. filix mas and D. erythrosora respectively in the bioavailable fraction, while the corresponding non-contaminated planted pots contained $0.030 \mathrm{mg} \mathrm{kg}^{-1}$ of these six REEs (data not shown) i.e. 20 times lower. Moreover, the 10 other REEs naturally present in 
the substrate (contaminated or not) accounted for a total composition of between $0.0036 \mathrm{mg} \mathrm{kg}^{-1}$ and 0.0057 $\mathrm{mg} \mathrm{kg}^{-1}$ (data not shown), being 147 and 110 times lower than the six REEs added. Thus, the bioavailable REE-background of the substrate was very low and nearly all of the REEs bioavailable for the plants arose from the six REEs added. The REE extractible fraction did not vary significantly between the two species of fern. However, the extractible fraction of $\mathrm{Yb}$ and $\mathrm{Y}$ were similar and were $\sim 3$ to 4 times higher than that of the four other REE species (La, Ce, Sm and Gd) (Fig. 4a). These results led us to determine the REE bioaccumulation factors for the two plants. The values for this parameter were much higher for $D$. erythrosora compared with D. filix-mas, especially for La, Ce, Sm and Gd (Fig. 4b). The values decreased in the order of $\mathrm{La}>\mathrm{Ce}>\mathrm{Sm}>\mathrm{Gd}>\mathrm{Y}>\mathrm{Yb}$ in the two species, with the exception of $\mathrm{Yb}$ in D. filix-mas.

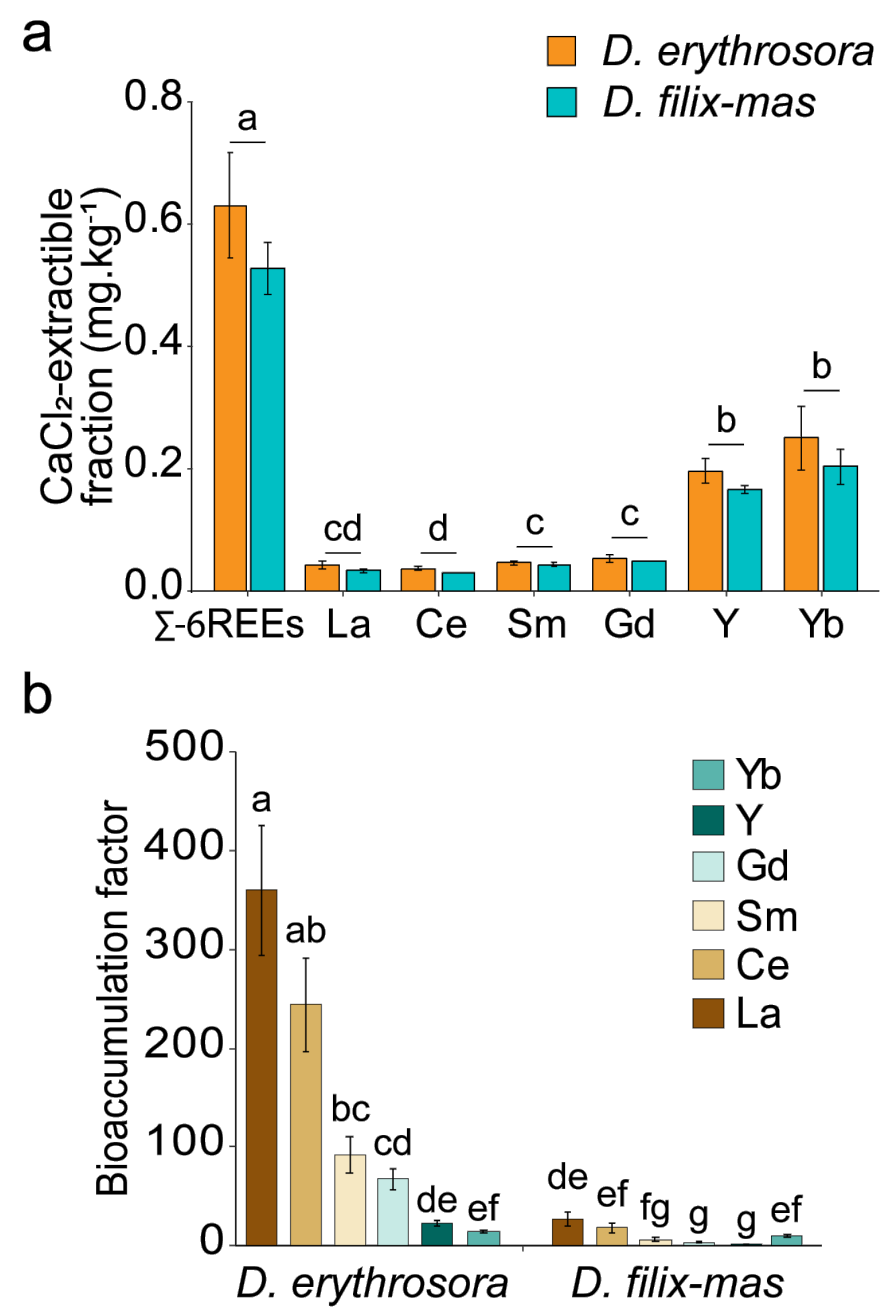

Fig. 4. (a) $\mathrm{CaCl}_{2}$-extractible fraction and (b) bioaccumulation factor of REEs of two contrasted Dryopteris species. (a) $\mathrm{CaCl}_{2}$-extractible fraction of the REEs in the substrate enriched with $2000 \mathrm{mg} \mathrm{kg}^{-1}$ REEs (333 $\mathrm{mg} \mathrm{kg}^{-1}$ of 6 REEs). $\Sigma(6-\mathrm{REEs}$ ) represents the sum of the six REEs. (b) Bioaccumulation factor (ratio of the accumulation in fronds over the extractible fraction in the substrate) of D. erythrosora and D. filix-mas $(n=3$, mean \pm s.d.). Different letters denote significant differences between the REE species $(P<0.05$, ANOVA, Tukey HSD). 
Environmental Chemistry

Volume: 17; Issue: 2; page: 191. Article ID: EN19182

DOI: $10.1071 / \mathrm{EN} 19182$

Macro- and micro-element composition under REE exposure

Principal component analysis (PCA) was performed and a Pearson correlation matrix of REE, and microand macro-elements was derived from the species belonging to the four genera used in the second screening (Fig. 5, Table S1, Table S2, Supplementary Material). This analysis was done to identify the putative correlations between macro-elements, micro-elements and REE accumulation in this set of ferns. The first two principal components of the PCA accounted for $48.3 \%$ of the observed changes, with the first principal component accounting for $30.7 \%$ (Fig. 5a). The REEs were clustered together, but of all the REEs, Yb showed a slightly lower correlation to the other REEs (Fig. 5a). In the first principal component, several macro- and micro-elements clustered with the REEs, such as $\mathrm{Ca}, \mathrm{Ni}, \mathrm{Mg}, \mathrm{Al}, \mathrm{B}, \mathrm{Fe}, \mathrm{Na}$ and $\mathrm{Mn}$ (Fig. 5a), while Mo was negatively correlated with the REEs (Fig. 5a). When analysing the correlation matrix, several macro- and micro-elements exhibited a significant positive correlation with the REEs. This observation was true for $\mathrm{Ca}, \mathrm{Al}$ and, to a lesser extent, $\mathrm{Na}$ (Fig. 5b). A significant negative correlation was found only between Mo and La (Fig. 5b). Yb was positively correlated with Ni and Mg (Fig. 5b).
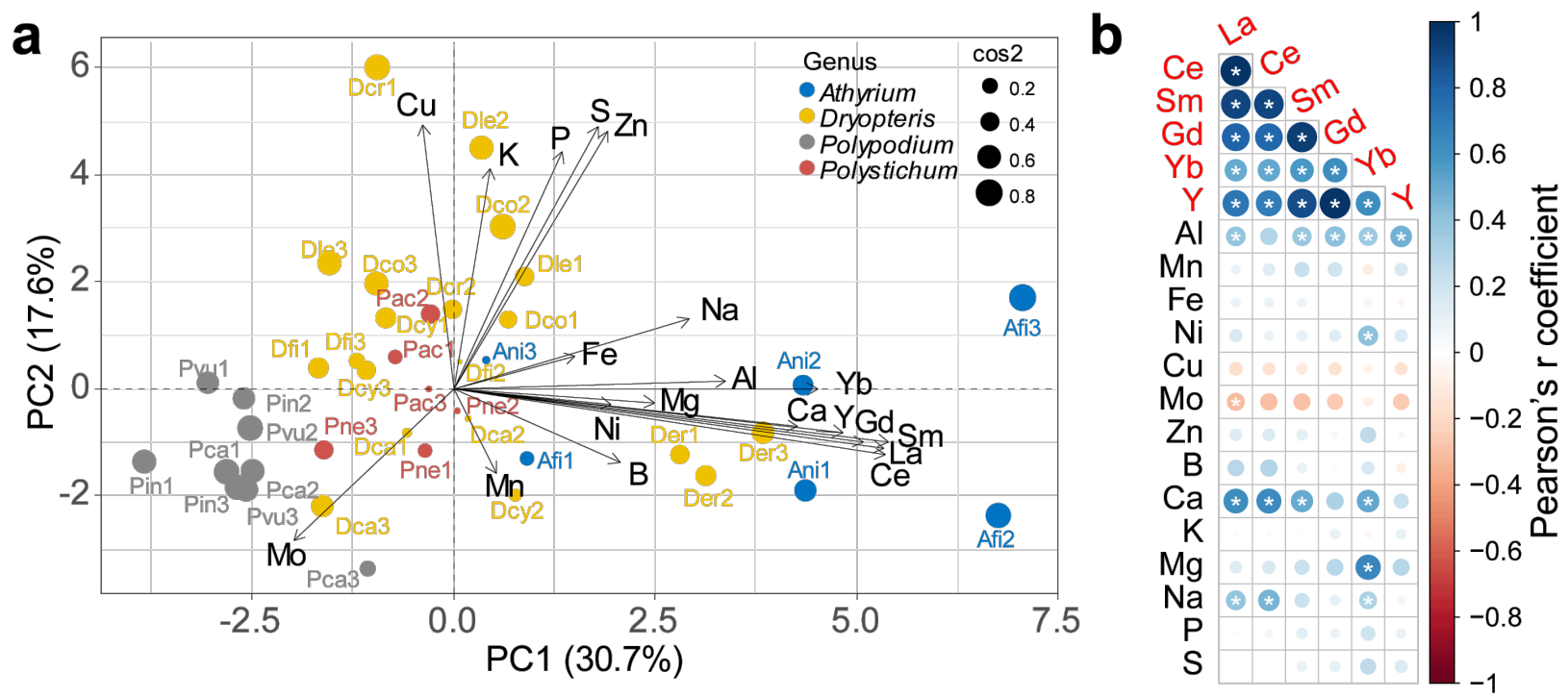

Fig. 5. Correlation between REEs and nutrient concentrations in fronds. (a) Principal component analysis of ferns exposed to $2000 \mathrm{mg} \mathrm{kg}^{-1}$ REEs. Ferns are colour-coded depending on their genera. Cos 2 indicates the contribution of the component for the PCA. (b) Pearson correlation matrix. White asterisks refer to significant $P$ values $(<0.05)$. REE, macro- and micro-elements were used as quantitative variables.

\section{Discussion}

The increasing use of REEs worldwide along with environmental contamination, especially around mining areas, raises the question of remediation of these sites. Plant-based remediation techniques can help reduce high REE concentrations in soils through the use of REE-accumulating plants (Chaney et al. 1997; 
Padmavathiamma and Li 2007; Liu et al. 2017). Relatively few plant species accumulating REEs are currently known; however, most of them are ferns (Ichihashi et al. 1992; Ozaki et al. 1997; Wei et al. 2001; Zhang et al. 2002; Shan et al. 2003; Lai et al. 2005, 2006; Liang et al. 2014), which could represent a yet unexplored reservoir of REE accumulators. Therefore, we screened a large panel of 49 fern species, all hardy and ornamental ferns, on a substrate spiked with six REEs (La, Ce, Sm, Gd, Yb and Y). The screening of hardy and ornamental plants has several advantages (Wu et al. 2018). For example, the use of non-edible plants restricts their entry into the food chain (Liu et al. 2008; Jelusic and Lestan 2015; Wu et al. 2018). Moreover, associated with their hardiness, these plants can be grown over several seasons and in diverse environments and climates. Furthermore, greater cultivation skills and knowledge of such plants has been developed, which help in their phytoremediation application (Liu et al. 2008; Jelusic and Lestan 2015; Wu et al. 2018).

Unlike previous studies (Ozaki et al. 1997), the present work is the first screening of ferns grown on an REE contaminated substrate to determine their ability to accumulate REEs. Using this screening strategy, we identified new REE-accumulating species. Of these, the species that accumulated the most ( $>200 \mathrm{mg}$ $\mathrm{kg}^{-1}$ ) were Onoclea sensibilis, followed by two species of Athyrium, namely, A. othophorum and A. filixfemina 'Victoriae'. The already known REE-accumulating species D. erythrosora ranked fourth, with more than $175 \mathrm{mg} \mathrm{kg}^{-1}$ accumulated in its fronds. Athyrium yokoscense (Ichihashi et al. 1992) has been previously reported as an REE-accumulating fern, thus it was noteworthy to find that other Athyrium species were also able to accumulate REEs. Similarly, two Blechnum species were able to accumulate moderate amounts of REEs in our study (55 mg kg-1 and $115 \mathrm{mg} \mathrm{kg}^{-1}$ for B. cordatum and B. penna-marina respectively); so far, only a single species, B. orientale, has been reported in the literature (Zhang et al. 2002; Liang et al. 2014). In addition, we identified here, for the first time, new plant REE accumulators belonging to other fern genera, including several Polystichum species, Onoclea sensibilis (Onocleaceae) and Woodwardia unigemmata (Blechnaceae), all accumulated more than $100 \mathrm{mg} \mathrm{kg}^{-1}$ REEs in their fronds.

In several cases, different species of the same genus have a similar accumulation potential. This was particularly true for the Athyrium species, which accumulated high REE concentrations, in contrast to the Polypodium species that had very low REE concentrations. A possible explanation could be a conserved mechanism of REE uptake and/or translocation in Athyrium that could be lacking in Polypodium species. Such a conserved trait for metal accumulation has been reported for Carya species that all accumulate REEs in their shoots (Wood and Grauke 2011) and also for Ni hyperaccumulation in several species of Alyssum and Cochlearia (Krämer 2010). Conversely, it was interesting to note the differences in REE accumulation between different species of a given genus. This was notably the case for Dryopteris: D. erythrosora was the highest accumulator in this genus, and D. filix-mas was the lowest accumulator in this genus. This 
variation in REE accumulation capacities between Dryopteris species may be correlated with the presence of specific mechanisms of REE absorption and/or translocation, which are not common to all Dryopteris species. A greater REE accumulation capacity was related to a higher ploidy level in Carya sp (Wood and Grauke 2011). These species native to xeric habitats could benefit from REE absorption since these elements might be involved in drought tolerance. This hypothesis also fits with the 'low resource requirement hypothesis' according to which polyploids exhibit lower growth rate and a higher anti-oxidant capacity to result in a better stress resistance (Deng et al. 2012). Therefore, plants with higher ploidy levels may be able to better cope with REEs compared with diploids. However, this was not the case in our study, since the REE accumulator D. erythrosora is triploid (Hori et al. 2016) and the non-accumulator D. filix mas is tetraploid (Sessa et al. 2012). This suggests the existence of other mechanisms involved in the observation of the REE accumulation trait in ferns, not linked to the ploidy level but possibly related to higher expression levels of non-specific REE-uptake and transfer systems.

A preferential accumulation of LREEs has been previously reported in REE-accumulating ferns (Ozaki et al. 1997; Wei et al. 2001; Wang et al. 2005). However, those studies were based on samples taken from ferns grown naturally in mining areas that were highly enriched in LREEs. Indeed, in these areas, LREEs are usually 3 to 60 times more abundant than HREEs, which result in an obvious bias when comparing the accumulation pattern of LREEs versus that of HREEs. To circumvent this bias in the present study, we exposed ferns to equal amounts of each REE. Nevertheless, we observed a preferential accumulation of LREEs (La, Ce, Sm) in fronds compared with HREEs ( $\mathrm{Gd}, \mathrm{Yb}, \mathrm{Y})$, which ranged from 2 to 8 times more LREEs than HREEs. More specifically, REE accumulation increased with the increase in ionic radii of the REE species $(\mathrm{La}>\mathrm{Ce}>\mathrm{Sm}>\mathrm{Gd}>\mathrm{Y}>\mathrm{Yb}$ ). This preferential accumulation of LREEs is unlikely to result from their bioavailability, as $\mathrm{Yb}$ and $\mathrm{Y}$ were 3 to 4 times more extractible than $\mathrm{La}, \mathrm{Ce}, \mathrm{Sm}$ and $\mathrm{Gd}$. Moreover, although the bioaccumulation factors were much lower for the non-accumulator $D$. filix mas, the same trend was observed and LREEs were also slightly more bioaccumulated. These statements support the hypothesis that an LREE import and transfer mechanism would be exacerbated in the REE-accumulating species and that it would also exist to a lesser extent in the non-REE-accumulating species. In species other than ferns, under equal amounts of each REE, the opposite pattern has been observed, with a preferential accumulation of HREEs, as shown in pokeweed (Phytolacca america) (Yuan et al. 2017), wheat (Triticum aestivum) (Ding et al. 2005, 2006) and soybean (Glycine max) (Ding et al. 2007).

The difference in REE fractionation between pteridophytes and angiosperms suggests various mechanisms of root-to-shoot transfer and selective enrichment. It has been shown that in wheat and soybean grown in hydroponic culture, the HREE enrichment observed in the leaves was mostly to the result of a larger transfer of HREEs complexed with organic ligands when compared with free LREE ions (Liang et 
al. 2008). Indeed, it appears that there is an increase in the stability of organic acid-REE complexes with increasing atomic number (Suzuki et al. 1980; Cantrell and Byrne 1987; Cheisson and Schelter 2019). Thus, free LREE ions would be more likely to adsorb to cell walls or precipitate (e.g. with phosphate) in the xylem. In $P$. americana, it has been suggested that asparagine, glutamate and histidine may be involved in the transfer of La and Y through the xylem (Wu et al. 2013). Similarly, Yuan et al. (2017) showed the important role of citrate in REE translocation in the same plant. In tomato, glutamate plays this role (Wu et al. 2009, 2013), whereas in wheat, REE translocation is mediated by citrate, malate and oxalate in the xylem sap (Ding et al. 2005, 2006). Overall, these data suggest the importance of several amino and organic acids in REE translocation in plants. However, future studies using transgenic lines with modulated amino or organic acid synthesis or transport are needed to fully validate these hypotheses.

In fern species, a different mechanism could be involved in the LREE enrichment observed in fronds. In Dicranopteris dichotoma, Wang et al. (2003) identified a low molecular weight LREE-binding peptide (Wang et al. 2003). Similarly, Lai et al. (2006) found another peptide specifically binding LREEs in the REE-accumulator fern Pronephrium simplex (Lai et al. 2006). These peptides may be involved in reducing LREE toxicity in plants. They may be ubiquitous in fern species that accumulate REEs and, therefore, could explain the LREE enrichment observed in pteridophytes. However, we cannot rule out a lower abundance of organic acids in fern species than in angiosperms, which precludes a relative HREE enrichment in fronds. In addition, angiosperms possess a xylem consisting of well-developed vessels and tracheids, while pteridophytes only have a tracheid-based xylem (Pittermann et al. 2011). Such differences in the waterconducting tissues, in particular in their structural composition (cell wall, organic ligands), could be a possible explanation for the enrichment of LREEs versus HREEs in the shoots of different plant lineages.

The ionome analysis showed that higher concentrations of several macro- and micro-elements were found in REE accumulating ferns. Indeed, the REE concentration was found to be positively correlated with most elements analysed, except for $\mathrm{Mo}$ and $\mathrm{Cu}$. This positive correlation with $\mathrm{Fe}$, as well as $\mathrm{Al}, \mathrm{Mg}, \mathrm{K}$ and $\mathrm{P}$, has also been reported in beech, spruce and oak (Brioschi et al. 2013). In Carya, accumulation of $\mathrm{Mg}, \mathrm{Ca}, \mathrm{Mn}$ and Fe was also positively associated with the foliar concentration of REEs (Wood and Grauke 2011). In D. erythrosora, we also observed an increase in Mn content together with REE accumulation. Furthermore, putative shared entry pathways in the roots for REEs, $\mathrm{Ca}$ and $\mathrm{Al}$ ions have been suggested in $P$. americana (Yuan et al. 2017). These observations support the existence of common uptake pathways for REEs and essential elements.

Additionally, the availability of elements in soils is highly $\mathrm{pH}$ dependent. The availability of elements such as $\mathrm{Al}, \mathrm{Fe}, \mathrm{Zn}, \mathrm{Cu}, \mathrm{B}$ and $\mathrm{Mn}$, as well as REEs, increases at low $\mathrm{pH}$ values, while the availability of elements such as Mo decreases at lower pH values (Fageria et al. 2004). The modified availability of these 
elements arising from soil $\mathrm{pH}$ could explain the correlations observed between REEs and essential elements. Wiche et al. (2016) observed an increase in Fe, Mn and P content, as well as REEs, in barley and white lupine (Wiche et al. 2016). The authors suggested that these elements could result from the dissolution of REE-phosphates, carbonates and Fe-Mn oxyhydroxides under the influence of root exudates (Wiche et al. 2016). This hypothesis was confirmed by Shan et al. (2002), who demonstrated that the bioavailability of REEs in soil is affected by soil $\mathrm{pH}$ and by low molecular weight organic acids (Shan et al. 2002). In addition, they highlighted the involvement of organic matter, Fe-, Mn- and Al-oxides, on the adsorption and desorption behaviour of REEs. Therefore, local acidification, as well as release of root exudates by the plants into the rhizosphere, could contribute to the increased availability and subsequent uptake of essential elements, together with REEs, by plants. A similar REE concentration pattern has also been observed between roots of $D$. dichotoma and soluble REEs in the soil (Wei et al. 2001). This similarity emphasises that soil-soluble REEs can be closely inter-related with the REE uptake by plants (Liu et al. 2017). However, in the present study, we did not find any difference in the $\mathrm{CaCl}_{2}$-extractible fraction of REEs in the substrate of the REE accumulating (D. erythrosora) and the non-REE accumulating (D. filix-mas) species. Also, the $\mathrm{pH}$ of the substrate for the two species was similar, at least in the bulk substrate, which indicated that there was no strong difference in the acidification potential between the two species. Further investigation will be needed to better understand the contrasting behaviour of these two species in term of accumulation of REEs and other elements.

\section{Conclusion}

The increasing use and spread of REEs have encouraged the scientific community to find environmentally friendly remediation techniques, such as phytoremediation, and to better understand the REE transfer mechanisms in plants. In this study, we identified new fern species that can accumulate REEs in their fronds. The high REE accumulation capacity identified in many species suggests a common putative trait of REE accumulation in ferns, as reported for the angiosperm genus Carya. We also report a close relationship between REE accumulation and the homeostasis of essential elements in ferns, which supports either the common uptake pathways and/or the behaviours in soils. Further metabolomic analyses of root exudates and the recognition of molecular determinants, such as transporters to be identified through comparative transcriptomics, will be needed to identify the putative ligands or proteins underlying the REE-accumulation trait. It will be particularly interesting to reveal the genetic and physiological determinants for LREE enrichment in pteridophytes versus HREE enrichment in angiosperms. Finally, the conservation of the LREE accumulation trait among these different fern species is of great interest for phytoremediation purposes since appropriate species can be chosen according to the area to be remediated. In the future, as it has already been done for other metal accumulating plants (Visioli et al. 2015), the isolation of rhizospheric 
Environmental Chemistry

Volume: 17; Issue: 2; page: 191. Article ID: EN19182

DOI: $10.1071 / \mathrm{EN} 19182$

and endophytic microorganisms (bacteria, fungi) will enable the establishment of microorganism-assisted phytoremediation. The inoculation of REE-accumulating plants with such organisms could improve the accessibility of nutrients to plants (Rengel and Marschner 2005) and, at the same time, increase the efficiency of REE phytoextraction.

\section{Supplementary material}

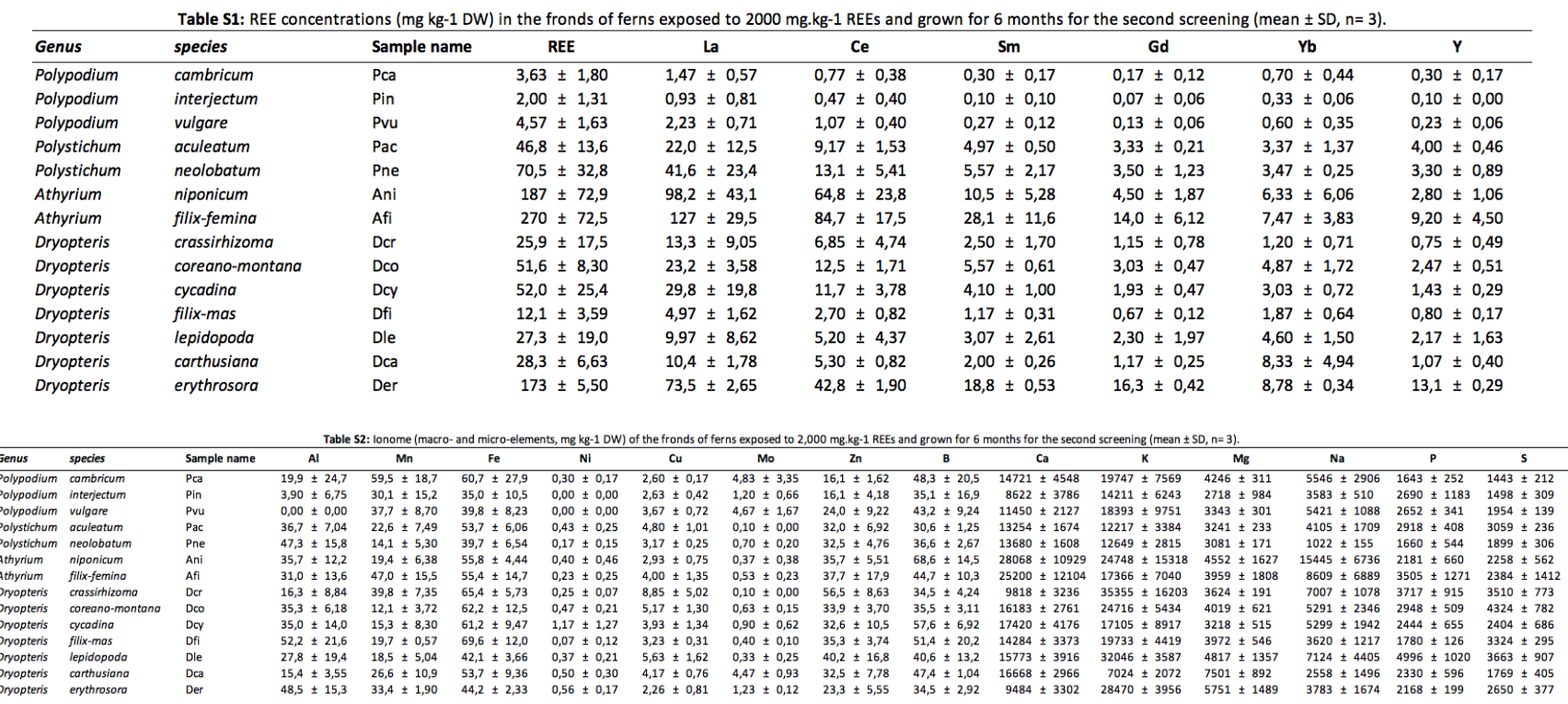

\section{Conflicts of interest}

The authors declare no conflicts of interest.

\section{Author contributions statement}

The authors' responsibilities were as follows: NG, MLJ and DB designed the research; NG, MLJ and DB performed the research; NG analysed the data; NG, MLJ, MC, EMG and DB evaluated the data; NG, MLJ, MC, EMG and DB wrote the manuscript. All authors read and approved the final manuscript.

\section{Acknowledgements}

This work has been supported by the French National Research Agency through the national program 'Investissements d'avenir' with the reference ANR-10-LABX-21-01/LABEX RESSOURCES21, the French National program EC2CO-ECODYN (RAREFERN), Inter-Carnot ICEEL (REECOVERY) and by the Région Grand-Est. We acknowledge Dr Nadia Morin-Crini for the ICP-MS analyses, and Christine Friry and Sarah Guinchard for technical support with plant growth and harvesting.

\section{References}

Binnemans, K., Jones, P. T., Blanpain, B., Van Gerven, T., Yang, Y., Walton, A. and Buchert, M. (2013) 'Recycling of rare earths: A critical review', Journal of Cleaner Production, 51, pp. 1-22. 
doi: 10.1016/j.jclepro.2012.12.037.

Brioschi, L., Steinmann, M., Lucot, E., Pierret, M. C., Stille, P., Prunier, J. and Badot, P. M. (2013) 'Transfer of rare earth elements (REE) from natural soil to plant systems: implications for the environmental availability of anthropogenic REE', Plant and Soil, 366(1-2), pp. 143-163. doi: 10.1007/s11104-012-1407-0.

Cantrell, K. J. and Byrne, R. H. (1987) 'Rare earth element complexation by carbonate and oxalate ions', Geochimica et Cosmochimica Acta, 51, pp. 597-605.

Chaney, R. L., Malik, M., Li, Y. M., Brown, S. L., Brewer, E. P., Angle, J. S. and Baker, A. J. (1997) 'Phytoremediation of soil metals.', Current Opinion in Biotechnology, 8, pp. 279-284.

Cheisson, T. and Schelter, E. J. (2019) 'Rare earth elements: Mendeleev's bane, modern marvels', Science, 493(February), pp. 489-493.

Ciacci, L., Reck, B. K., Nassar, N. T. and Graedel, T. E. (2015) 'Lost by design', Environmental Science \& Technology, 49(16), pp. 9443-9451. doi: 10.1021/es505515z.

Cotton, S. (2006) Lanthanide and actinide chemistry. John Wiley, Lanthanide and Actinide Chemistry. John Wiley. doi: 10.1002/0470010088.

Deng, B., Du, W., Liu, C., Sun, W., Tian, S. and Dong, H. (2012) 'Antioxidant response to drought, cold and nutrient stress in two ploidy levels of tobacco plants : low resource requirement confers polytolerance in polyploids?', Plant Growth Regulation, 66(1), pp. 37-47. doi: https://doi.org/10.1007/s10725-011-9626-6.

Ding, S., Liang, T., Zhang, C., Huang, Z., Xie, Y. and Chen, T. (2006) 'Fractionation mechanisms of rare earth elements (REEs) in hydroponic wheat : an application for metal accumulation by plants', Environmental Science \& Technology, 40(8), pp. 2686-2691.

Ding, S. M., Liang, T., Yan, J. C., Zhang, Z. L., Huang, Z. C. and Xie, Y. N. (2007) 'Fractionations of rare earth elements in plants and their conceptive model', Science in China, Series C: Life Sciences, 50(1), pp. 47-55. doi: 10.1007/s11427-007-2040-7.

Ding, S. M., Liang, T., Zhang, C. S., Yan, J. C. and Zhang, Z. L. (2005) 'Accumulation and fractionation of rare earth elements (REEs) in wheat: Controlled by phosphate precipitation, cell wall absorption and solution complexation', Journal of Experimental Botany, 56(420), pp. 27652775. doi: 10.1093/jxb/eri270.

Djingova, R., Ivanova, J., Wagner, G., Korhammer, S. and Markert, B. (2001) 'Distribution of lanthanoids, $\mathrm{Be}, \mathrm{Bi}, \mathrm{Ga}, \mathrm{Te}, \mathrm{Tl}$, Th and $\mathrm{U}$ on the territory of Bulgaria using Populus nigra 
"Italica" as an indicator', Science of the Total Environment, 280(1-3), pp. 85-91. doi: 10.1016/S0048-9697(01)00817-8.

Fageria, N. K., Baligar, V. C. and Clark, R. B. (2004) Micronutrients in Crop Production, Advances in Agronomy. Elsevier Inc. doi: 10.1016/s0065-2113(02)77015-6.

Gambogi, J. (2018) Rare Earths, Metals and minerals: U.S. Geological Survey Minerals Yearbook 2015. doi: 10.1016/j.ijporl.2012.07.018.

Gonzalez, V., Vignati, D. A. L., Leyval, C. and Giamberini, L. (2014) 'Environmental fate and ecotoxicity of lanthanides: Are they a uniform group beyond chemistry?', Environment International, 71, pp. 148-157. doi: 10.1016/j.envint.2014.06.019.

Hedrick, J. B. (2003) Rare Earths, Metals and minerals: U.S. Geological Survey Minerals Yearbook 2001.

Hori, K., Watano, Y. and Murakami, N. (2016) 'Hybrid origin of the apogamous fern Dryopteris hondoensis (Dryopteridaceae)', Acta phytotaxonomica et geobotanica, 67(3), pp. 133-146. doi: 10.18942/apg.201609.

Ichihashi, H., Morita, H. and Tatsukawa, R. (1991) 'Rare earth elements (REEs) in naturally grown plants in relation to their variation in soils.', Environmental pollution (Barking, Essex : 1987), 76(2), pp. 157-162. doi: 10.1016/0269-7491(92)90103-H.

Ikhlayel, M. (2017) 'Evaluation of the environmental impacts of rare earth elements production', International Journal of Environmental Studies. Routledge, 74(6), pp. 939-957. doi: 10.1080/00207233.2017.1341737.

Jelusic, M. and Lestan, D. (2015) 'Remediation and reclamation of soils heavily contaminated with toxic metals as a substrate for greening with ornamental plants and grasses', Chemosphere, 138, pp. 1001-1007. doi: 10.1016/j.chemosphere.2014.12.047.

Krämer, U. (2010) 'Metal hyperaccumulation in plants', Annual Review of Plant Biology, 61(1), pp. 517-534. doi: 10.1146/annurev-arplant-042809-112156.

Lai, Y., Wang, Q. Q., Yan, W. W., Yang, L. M. and Huang, B. L. (2005) 'Preliminary study of the enrichment and fractionation of REEs in a newly discovered REE hyperaccumulator Pronephrium simplex by SEC-ICP-MS and MALDI-TOF/ESI-MS', Journal of Analytical Atomic Spectrometry, 20(8), pp. 751-753. doi: 10.1039/b501766a.

Lai, Y., Wang, Q., Yang, L. and Huang, B. (2006) 'Subcellular distribution of rare earth elements and characterization of their binding species in a newly discovered hyperaccumulator 
Pronephrium simplex', Talanta, 70(1), pp. 26-31. doi: 10.1016/j.talanta.2005.12.062.

Liang, T., Ding, S., Song, W., Chong, Z., Zhang, C. and Li, H. (2008) 'A review of fractionations of rare earth elements in plants', Journal of Rare Earths, 26(1), pp. 7-15. doi: 10.1016/S10020721(08)60027-7.

Liang, T., Li, K. and Wang, L. (2014) 'State of rare earth elements in different environmental components in mining areas of China', Environmental Monitoring and Assessment, 186(3), pp. 1499-1513. doi: 10.1007/s10661-013-3469-8.

Liu, C., Yuan, M., Liu, W., Guo, M., Huot, H., Tang, Y., Laubie, B., Simonnot, M., Morel, J. and Qiu, R. (2017) 'Element case studies: Rare earth elements’, in Van der Ent, A., Echevarria, G., Baker, A., and Morel, J.-L. (eds) Agromining: Farming for metals. mineral resource reviews. Springer, Cham.

Liu, J. nv, Zhou, Q. xing, Sun, T., Ma, L. Q. and Wang, S. (2008) 'Growth responses of three ornamental plants to $\mathrm{Cd}$ and $\mathrm{Cd}-\mathrm{Pb}$ stress and their metal accumulation characteristics', Journal of Hazardous Materials, 151(1), pp. 261-267. doi: 10.1016/j.jhazmat.2007.08.016.

Long, K. R., Van Gosen, B. S., Foley, N. K. and Cordier, D. (2010) The principal rare earth elements deposits of the United States: A summary of domestic deposits and a global perspective, U.S. Geological Survey Scientific Investigations Report 2010-5220. doi: 10.1007/978-90-4818679-2_7.

Ozaki, T., Enomoto, S., Minai, Y., Ambe, S., Ambe, F. and Makide, Y. (2000) 'Beneficial effect of rare earth elements on the growth of Dryopteris erythrosora', Journal of Plant Physiology, 156(3), pp. 330-334. doi: 10.1016/S0176-1617(00)80070-X.

Ozaki, T., Enomoto, S., Minai, Y., Ambe, S., Ambe, F. and Tominaga, T. (1997) 'Determination of lanthanides and other trace elements in ferns by instrumental neutron activation analysis', Journal of Radioanalytical and Nuclear Chemistry, 217(1), pp. 117-124. doi:

10.1007/BF02055359.

Padmavathiamma, P. K. and Li, L. Y. (2007) 'Phytoremediation technology: Hyper-accumulation metals in plants', Water, Air, and Soil Pollution, 184(1-4), pp. 105-126. doi: 10.1007/s11270007-9401-5.

Pagano, G., Guida, M., Tommasi, F. and Oral, R. (2015) 'Health effects and toxicity mechanisms of rare earth elements - Knowledge gaps and research prospects', Ecotoxicology and Environmental Safety. Elsevier, 115, pp. 40-48. doi: 10.1016/j.ecoenv.2015.01.030. 


\section{Environmental Chemistry \\ Volume: 17; Issue: 2; page: 191. Article ID: EN19182 \\ DOI: $10.1071 / \mathrm{EN} 19182$}

Pittermann, J., Limm, E., Rico, C. and Christman, M. A. (2011) 'Structure-function constraints of tracheid-based xylem: A comparison of conifers and ferns', New Phytologist, 192(2), pp. 449461. doi: 10.1111/j.1469-8137.2011.03817.x.

Ramos, S. J., Dinali, G. S., de Carvalho, T. S., Chaves, L. C., Siqueira, J. O. and Guilherme, L. R. G. (2016) 'Rare earth elements in raw materials and products of the phosphate fertilizer industry in South America: Content, signature, and crystalline phases', Journal of Geochemical Exploration. Elsevier B.V., 168, pp. 177-186. doi: 10.1016/j.gexplo.2016.06.009.

Rengel, Z. and Marschner, P. (2005) 'Nutrient availability and management in the rhizosphere: Exploiting genotypic differences', New Phytologist, 168(2), pp. 305-312. doi: 10.1111/j.14698137.2005.01558.x.

Rim, K. T., Koo, K. H. and Park, J. S. (2013) 'Toxicological evaluations of rare earths and their health impacts to workers: a literature review', Safety and Health at Work. Elsevier Masson SAS, 4(1), pp. 12-26. doi: 10.5491/SHAW.2013.4.1.12.

Salazar, M. J. and Pignata, M. L. (2014) 'Lead accumulation in plants grown in polluted soils. Screening of native species for phytoremediation', Journal of Geochemical Exploration, 137, pp. 29-36. doi: 10.1016/j.gexplo.2013.11.003.

Sessa, E. B., Zimmer, E. A. and Givnish, T. J. (2012) 'Unraveling reticulate evolution in North American Dryopteris (Dryopteridaceae)', BMC Evolutionary Biology, 12(104). doi: 10.1186/1471-2148-12-104.

Shahandeh, H. and Hossner, L. R. (2000) 'Plant screening for chromium phytoremediation', International Journal of Phytoremediation, 2(1), pp. 31-51. doi: 10.1080/15226510008500029. Shan, X. quan, Lian, J. and Wen, B. (2002) 'Effect of organic acids on adsorption and desorption of rare earth elements', Chemosphere, 47(7), pp. 701-710. doi: 10.1016/S0045-6535(02)00032-2. Shan, X., Wang, H., Zhang, S., Zhou, H., Zheng, Y., Yu, H. and Wen, B. (2003) 'Accumulation and uptake of light rare earth elements in a hyperaccumulator Dicropteris dichotoma', Plant Science, 165(6), pp. 1343-1353. doi: 10.1016/S0168-9452(03)00361-3.

Suzuki, Y., Yokoi, S., Katoh, M., Minato, M. and Takizawa, N. (1980) 'Stability constants of rare-earth complexes with some organic ligands', in McCarthy, G. J., Rhyne, J. J., and Silber, H. B. (eds) The rare earths in mordern science and technology. Springer, Boston, MA, pp. 121-126. doi: https://doi.org/10.1007/978-1-4613-3054-7_22.

Tyler, G. (2004) 'Rare earth elements in soil and plant systems - A review', Plant and Soil, 267, 
pp. 191-206.

Visioli, G., D’Egidio, S. and Sanangelantoni, A. M. (2015) 'The bacterial rhizobiome of hyperaccumulators: future perspectives based on omics analysis and advanced microscopy', Frontiers in Plant Science, 5(January). doi: 10.3389/fpls.2014.00752.

Wakabayashi, T., Ymamoto, A., Kazaana, A., Nakano, Y., Nojiri, Y. and Kashiwazaki, M. (2016) 'Antibacterial, antifungal and nematicidal activities of rare earth ions', Biological Trace Element Research, 174(2), pp. 464-470. doi: 10.1007/s12011-016-0727-y.

Wang, H., Shan, X.-Q., Zhang, S. and Wen, B. (2003) 'Preliminary characterization of a lightrare-earth-element-binding peptide of a natural perennial fern Dicranopteris dichotoma.', Analytical and bioanalytical chemistry, 376(1), pp. 49-52. doi: 10.1007/s00216-003-1853-X. Wang, L. F., Ji, H. B., Bai, K. Z., Li, L. B. and Kuang, T. Y. (2005) 'Photosynthetic characterization of the plant Dicranopteris dichotoma Bernh. in a rare earth elements mine', Journal of Integrative Plant Biology, 47(9), pp. 1092-1100. doi: 10.1111/j.17447909.2005.00138.x.

Wiche, O., Kummer, N. A. and Heilmeier, H. (2016) 'Interspecific root interactions between white lupin and barley enhance the uptake of rare earth elements (REEs) and nutrients in shoots of barley', Plant and Soil, 402(1-2), pp. 235-245. doi: 10.1007/s11104-016-2797-1.

Wood, B. W. and Grauke, L. J. (2011) 'The rare-earth metallome of pecan and other Carya', Journal of the American Society for Horticultural Science, 136(6), pp. 389-398.

Wu, J., Chen, A., Peng, S., Wei, Z. and Liu, G. (2013) 'Identification and application of amino acids as chelators in phytoremediation of rare earth elements lanthanum and yttrium', Plant and Soil, 373(1-2), pp. 329-338. doi: 10.1007/s11104-013-1811-0.

Wu, J. L., Wei, Z. G., Zhao, H. Y., Li, H. X. and Hu, F. (2009) 'The role of amino acids in the long-distance transport of La and Y in the xylem sap of tomato', Biological Trace Element Research, 129(1-3), pp. 239-250. doi: 10.1007/s12011-008-8277-6.

Wu, M., Luo, Q., Liu, S., Zhao, Y., Long, Y. and Pan, Y. (2018) 'Screening ornamental plants to identify potential Cd hyperaccumulators for bioremediation', Ecotoxicology and Environmental Safety. Elsevier Inc., 162(March), pp. 35-41. doi: 10.1016/j.ecoenv.2018.06.049.

Yuan, M., Guo, M. N., Liu, W. S., Liu, C., van der Ent, A., Morel, J. L., Huot, H., Zhao, W. Y., Wei, X. G., Qiu, R. L. and Tang, Y. T. (2017) 'The accumulation and fractionation of rare earth elements in hydroponically grown Phytolacca americana L', Plant and Soil, 421(1-2), pp. 67-82. 
doi: $10.1007 / \mathrm{s} 11104-017-3426-3$.

Wei Z., Ming, Y., Xun, Z., Fashui, H., Bing, L., Ye, T., Guiwen, Z. and Chunhua, Y. (2001)

'Rare earth elements in naturally grown fern Dicranopteris linearis in relation to their variation in soils in South-Jiangxi region (Southern China)', Environmental Pollution, 114(3), pp. 345-355. doi: 10.1016/S0269-7491(00)00240-2.

Yuan, M., Liu, C., Liu, W.-S., Guo, M.-N., Morel, J. L., Huot, H., Yu, H.-J., Tang, Y.-T. and Qiu, R.-L. (2018) 'Accumulation and fractionation of rare earth elements (REEs) in the naturally grown Phytolacca americana L. in southern China', International Journal of Phytoremediation, 20(5), pp. 415-423. doi: https://doi.org/10.1080/15226514.2017.1365336.

Zhang, Z., Sugawara, K., Hatayama, M., Huang, Y. and Inoue, C. (2014) 'Screening of Asaccumulating plants using a foliar application and a native accumulation of As', International Journal of Phytoremediation, 16(3), pp. 257-266. doi: 10.1080/15226514.2013.773277.

Zhang, Z. Y., Wang, Y. Q., Li, F. L., Xiao, H. Q. and Chai, Z. F. (2002) 'Distribution characteristics of rare earth elements in plants from a rare earth ore area', Journal of Radioanalytical and Nuclear Chemistry, 252(3), pp. 461-465. doi: 10.1023/A:1015834232718. Zhuang, M., Wang, L., WU, G., Wang, K., Jiang, X., Liu, T., Xiao, P., Yu, L., Jiang, Y., Song, J., Zhang, J., Zhou, J., Zhao, J., Chu, Z. (2017) 'Health risk assessment of rare earth elements in cereals from mining area in Shandong, China', Scientific Reports, 7, 9772. doi: 10.1038/s41598017-10256-7 